\title{
UNITY AND DIVERSITY IN CANADIAN FEDERALISM: IDEALS AND METHODS OF MODERATION
}

\author{
W. R. LEDERMAN*
}

Canada is a federal country of great extent and variety in which we respect both unity and diversity. This is difficult to do, but we have now been doing it with a large measure of success for well over 100 years. The total process of governing Canada revolves about a division and distribution of primary legislative capacities or powers by two lists of subjects, one list for the federal parliament (primarily section 91 of the B.N.A. Act) and the other for each of the provincial legislatures (primarily section 92 of the B.N.A. Act). Instead of subjects, one might speak of categories or classes. For the most part, sections 91 and 92 taken together comprise a complete system for the distribution of primary legislative powers and responsibilities in Canada over virtually the whole range of actual and potential law-making. The courts have held the distribution is complete, with some very few exceptions that prove the rule. The exceptions are concerned with certain specific rights to use of the French or English languages, certain specific rights to denominational schools, and free trade across provincial borders. Without disparaging the importance of these exceptions, it is fair to point out that nearly all of our constitutional jurisprudence in the courts for 100 years has concentrated on issues of the distribution of powers.

My concern in this paper is to offer some thoughts on the nature and quality of the judicial interpretation of sections 91 and 92 of the B.N.A. Act over the years. Until the end of 1949, of course, the dominant court was the Judicial Committee of the Privy Council in London. Only since 1949 has the Supreme Court of Canada emerged from the shadow of the Judicial Committee and become supreme in law as well as in name. So, while we are celebrating this year the 100th anniversary of the creation of the Supreme Court of Canada, we are only celebrating the 25th anniversary of the supremacy of the Supreme Court of Canada as the final tribunal of appeal for Canadians.

The definitive study of the Privy Council period in constitutional interpretation was published in 1971 by Professor Alan C. Cairns. This is an essay of about 45 pages in the Canadian Journal of Political Science, entitled "The Judicial Committee and Its Critics." I agree with Professor Cairns's conclusions, so I give them rather fully in his own words: ${ }^{1}$

In brief, if the performance of the Privy Council was, as its critics suggested, replete with inconsistencies and insensitivity, the confused outpourings of the critics displayed an incoherence completely inadequate to guide judges in decision-making. To contrast the performance of the Judicial Committee with the performance of its opponents is to ignore the dissimilarity of function between artist and critic. It is however clear that the Judicial Committee was much more sensitive to the federal nature of Canadian society than were the critics. From this perspective at least the policy output of British judges was far more harmonious with the underlying pluralism of Canada than were the confused prescriptive statements of her opponents. For those critics, particularly on the left who wished to transform society, this qualified defence of the Judicial Committee will lack conviction. However, such critics have an obligation not only to justify their objectives but also the role they advocated for a non-elected court in helping to attain them.

Whether the decline in the problem-solving capacity of governments in the federal system was real or serious enough to support the criticism which the Privy Council encountered involves a range of value judgments and empirical observations of a very

- Professor of Law, Queen's University, Kingston, Ontario. Visiting Research Professor, Centre of Research in Public Law, University of Montreal, 1974-75.

1 Cairns, A. C., "The Judicial Committee and Its Critics", (1971) Canadian Journal of Political Science, 301 at $343-4$. 
complex nature. The purpose of this paper has been only to provide documentation for the minimum statement that a strong case can be made for the Judicial Committee, and to act as a reminder that the basic question was jurisprudential, a realm of discussion in which neither the Privy Council, its critics, nor its supporters proved particularly illuminating.

Note that Professor Cairns deplores the general confusion that has reigned concerning a positive philosophical jurisprudence of constitutional judicial review in Canada. Secondly, note that in any event he thinks the record of their Lordships of the Privy Council is a lot better in this regard than that of their critics. Note finally that he says the basic question was and is jurisprudential.

Accordingly, writing as a critic who has been both chastened and challenged by what Cairns has said, I now offer some thoughts on the essential operating jurisprudence of Canadian federalism. I assume in so doing that judicial review at all levels, and especially at the highest level, is essential to the process of interpreting a federal distribution of primary legislative powers. I have made the case for this proposition several times in earlier published essays, ${ }^{2}$ and I will return to it near the end of this essay. What I now do is to select two points to develop about the essential operating jurisprudence of our federal distribution of legislative powers, and in the course of discussing them, I will offer some opinions on the quality of what judges have said they were doing, and on what other critics have said the judges should have been doing.

In the first place, I address the nature of the Canadian system for the distribution of legislative powers. This then leads in the second place to a consideration of the significance of what I prefer to call the federal general power, but which often is called the federal peace, order and good government power.

Starting then with the nature of the Canadian federal system, we find that our way of distributing legislative powers has been to set up two rather detailed lists of federal and provincial legislative capacities. In an earlier essay, I described the two lists and the methods of interpreting them in these terms: ${ }^{3}$

The federal distribution of legislative powers and responsibilities in Canada is one of the facts of life when we concern ourselves with the many important social, political, economic or cultural problems of our country. Over the whole range of actual and potential law-making, our constitution distributes powers and responsibilities by two lists of categories or classes - one list for the federal parliament (primarily section 91 of the B.N.A. Act), the other for each of the provincial legislatures (primarily section 92 of the B.N.A. Act). For instance, the federal list includes regulation of trade and commerce, criminal law, and a general power to make laws in all matters not assigned to the provinces. Examples from the provincial list are property and civil rights in the province, local works and undertakings, and all matters of a merely local or private nature in the province.

These federal and provincial categories of power are expressed, and indeed have to be expressed, in quite general terms. This permits considerable flexibility in constitutional interpretation, but also it brings much over-lapping and potential conflict between the various definitions of powers and responsibilities. To put the same point in another way, our community life - social, economic, political, and cultural - is very complex and will not fit neatly into any scheme of categories or classes without considerable overlap and ambiguity occurring. There are inevitable difficulties arising from this that we must live with so long as we have a federal constitution.

Accordingly the courts must continually assess the competing federal and provincial lists of powers against one another in the judicial task of interpreting the constitution. In the course of judicial decisions on the B.N.A. Act, the judges have basically done one

${ }^{2}$ Lederman, W. R., "The Independence of The Judiciary”, (1956) 34 Can. Bar Rev. 769 and 1139.

"The Balanced Interpretation of the Federal Distribution of Legislative Powers in Canada", MacPherson and Crepeau (eds.), The Future of Canadian Federalism (1965), University of Toronto Press, 91.

${ }^{3}$ Lederman, W. R., "The Concurrent Operation of Federal and Provincial Laws in Canada", (1962-63) 9 McGill L.J. 185. 
of two things. First, they have attempted to define mutually exclusive spheres for federal and provincial powers, with partial success. But, where mutual exclusion did not seem feasible or proper, the courts have implied the existence of concurrent federal and provincial powers in the overlapping area, with the result that either or both authorities have been permitted to legislate provided their statutes did not in some way conflict one with the other in the common area.

The words quoted imply the point I now wish to develop more explicitly. We have here two lists of powers that are in total competition one with the other in all their parts, total competition, that is, to embrace challenged provincial or federal statutes and to stamp them with legitimacy as exercises of provincial or federal legislative power respectively. The federal general power competes with the provincial general power, the federal criminal law power competes with the provincial property power, and so on. Proper use of words good grammar and syntax - is essential as a starting point for the expression of a scheme of division of powers. But it is only the starting point, and it is a mistake to think that the task of interpretation is grammatical and syntactical only, treating the constitutional document in isolation from the economic, social and cultural facts of life of the society to which the constitutional document relates, both historically and currently. Yet this has frequently been done in Canada. The famous O'Connor Report of $1939^{4}$ castigates the Judicial Committee because it perversely contradicted the so-called "plain words" of section 91 of the B.N.A. Act. Many years later, Professor G. P. Browne, in his book on the Privy Council period, ${ }^{5}$ discovered full justification for the Judicial Committee's results in the grammar and syntax of the same so-called "plain words" of sections 91 and 92. So, O'Connor and Browne simply cancel one another out, and in so doing demonstrate the truth of the following remarks by Professor Hans Kelsen. Kelsen said (speaking of the constitution of the United Nations): ${ }^{6}$

Since the law is formulated in words and words have frequently more than one meaning, interpretation of the law, that is determination of its meaning, becomes necessary. Traditional jurisprudence distinguishes various methods of interpretation: the historical, in contrast to the grammatical, an interpretation according to the "spirit", in opposition to a literal interpretation keeping to the words. None of these methods can claim preference unless the law itself prescribes the one or the other. The different methods of interpretation may establish different meanings of one and the same provision. Sometimes, even one and the same method, especially the so-called grammatical interpretation, leads to contradictory results. It is incumbent upon the law-maker to avoid as far as possible ambiguities in the text of the law; but the nature of language makes the fulfilment of this task possible only to a certain degree.

So I say one needs to insist that the power-conferring words and phrases of section 91 and 92 must be related to the cultural, social and economic realities of the society for which they were and are intended, both historically and currently, if they are to make sense as basic guidelines for government at both the provincial and federal levels.

To illustrate what I mean, I wish to take up a neglected historical point. I refer to the historically established meaning of the phrase "Property and Civil Rights" in central British North America from 1774 to 1867. The phrase as you know comes from the Quebec Act of 1774 of the Imperial Parliament, ${ }^{7}$ which provided that French law and custom were to obtain respecting property and

4 Report by W. F. O'Connor, The Parliamentary Counsel to The Honourable the Speaker of the Senate relating to "The Enactment of the B.N.A. Act, 1867, any lack of consonance between its terms and judicial construction of them and cognate matters." (1939) Ottawa, The King's Printer.

- Browne, G. P., The Judicial Committee and the British North America Act, (1967), U. of T. Press.

- Kelsen, H., The Law of the United Nations (London: Stevens and Sons Ltd.,) (1951) at xiii-xv.

714 George III, c. 83 (U.K.). 
civil rights in the royal colony of Quebec. This covered all the law except English criminal law, and except the English public law that came to Quebec as necessary context for English colonial governmental institutions. In her recent book on the subject, Dr. Hilda Neatby, a distinguished Canadian historian, has demonstrated from the official documents of the time that the phrase property and civil rights in the Quebec Act had and was intended to have this very broad significance. $^{8}$ Moreover, these words retained this very broad significance in Upper and Lower Canada between 1791 and 1841, and in the United Province of Canada, 1841-1867. The Fathers of Confederation knew all about this - they lived with it every day - and naturally they took the broad scope of the phrase for granted. Accordingly they realized that, in setting up a central parliament in their new federal system, a considerable list of particular central powers would have to be specified in some detail as subtractions from the historically established meaning of the phrase property and civil rights. Otherwise the use of that phrase in the provincial list would leave very little for the new central parliament. Because of this, I reiterate, the Fathers of Confederation knew that a general grant of power to the central parliament in all matters not assigned to the provinces would in and by itself not be enough to give the central parliament all the powers they wished it to have, for example over banking, or marriage and divorce or bills of exchange. I am not just speculating at large when I say this. You can see it in the text of both the Quebec and the London Resolutions: ${ }^{\circ}$

Quebec Resolutions

43 (15) Property and civil rights, excepting those portions thereof assigned to the General Parliament.

(18) And generally all matters of a private or local nature, not assigned to the General Parliament.

London Resolutions

41 (15) Property and civil rights (including the solemnization of marriage) excepting portions thereof assigned to the General Parliament.

(18) And generally all matters of a Private or Local Nature not assigned to the General Parliament.

The same point also emerges from a comparison of the penultimate draft of the B.N.A. Act with the final draft that was enacted. ${ }^{10}$ I infer from the comparison that the "notwithstanding" clause in the opening words of section 91 and the "deeming" clause in the closing words were designed to ensure that the twentynine specific categories in the original federal list were to be taken as withdrawn from the historic scope of the provincial property and civil rights clause, and withdrawn also from the new provincial category of things generally of a local and private nature in the province.

In other words, the implication is plain that this double-listing was done because the Fathers of Confederation, the Colonial Secretary and the parliamentary draftsmen were all satisfied that it was necessary; that the rather long and particular federal list, supported by the "notwithstanding" clause and the "deeming" clause, was essential if items like banking, marriage and divorce, copyright, connecting railways, and so on were to be within the power of the new federal parliament, where they wanted them to be.

Accordingly, it follows that the twenty-nine specific categories of federal parliamentary power originally listed in section 91 are not merely illustrations of what would have been embraced anyway by the federal general power to make laws in all matters not assigned to the provinces. For the reasons of historical fact that I have given about the phrase property and civil rights, the federal list

${ }^{8}$ Quebec, 1769-1791, The Canadian Centenary Series, (1966), McClelland and Stewart Ltd., Toronto.

9 Pope, J., Confederation, (1895), Toronto, The Carswell Co. Ltd., 1895, 47 and 108.

10 Id. at 233-236. 
was not just superfluous grammatical prudence, it was compelled by historical necessity and has independent standing. Many if not most of the twenty-nine enumerated heads in section 91 confer powers on the federal parliament that would not have been attracted to that parliament by the federal general power alone in single-handed competition with the historic provincial property and civil rights clause.

The result of this reasoning about the nature of section 91 may be recapitulated as follows. The twenty-nine more particular powers, the so-called enumerated powers, add greatly to the competence that would have been invested in the federal parliament by the federal general power alone, though no doubt there is a modest amount of overlapping. On the other hand, the federal general power is no mere appendage to the twenty-nine enumerated powers, an appendage labelled "for emergencies only". It covers considerable ground that the enumerated powers do not cover. What then do we see when we look at the complete picture afforded by sections 91 and 92 ? I say we see a total system of powerdistribution wherein thirty heads of federal power, including a national general and residuary power, compete with sixteen heads of provincial power, one of which is a local general and residuary power. The grammar and syntax of sections 91 and 92 are as consistent with this result as with any other, and the history of central British North America from 1774 to 1867 confirms this alternative as the correct picture of the system. This is why I describe Canadian power-distribution as the total competition of thirty federal heads of power with sixteen provincial heads of power. Because of amendments since 1867 we should now speak of thirty-two and sixteen. So potentially the logical extent of this competition is all the permutations and combinations of thirty-two versus sixteen. The picture is indeed a complex one, but anything less is surely oversimplification.

When the time came to compose a federal constitution for Canada, we can count ourselves fortunate that the history of property and civil rights in the royal colony of Quebec and the successor colonies compelled the use of two rather long lists of federal and provincial powers. The many power-conferring phrases used were all equal in status as parts of a single system and thus had each to be read in a context that included all the others. As a result, there had to be restraint, moderation and mutual modification in the scope that was to be given any one of them.11 The federal trade and commerce clause could not be allowed to destroy all commercial significance for the provincial property and civil rights clause, or vice versa. The provincial property power could not be extended indefinitely at the expense of the federal criminal law power, or vice versa, and so on.

As Canada expanded westward geographically and accepted heavy immigration, the ccuntry became more and not less diverse. The kind of a federal document that history gave us facilitated the development of a carefully balanced federalism that accommodated old and new diversities as well as ensuring essential unities. Unique flexibility for Canada comes from having many power-conferring phrases in competition with one another, and the equilibrium points established between them portray the critical detail of Canadian federalism. The power-conferring phrases themselves are given by the B.N.A. Act, but the equilibrium points are not to be found there. They have necessarily been worked out painstakingly by judicial interpretation and precedent over many years. Furthermore, particular equilibrium points are not fixed for all time. As conditions in the country genuinely change and truly new statutory schemes are enacted, judicial interpretation can adjust and refine the equilibrium of the

11 Citizens' Insurance Company v. Parsons, (1881-82) 7 A.C. 94, 106-110. 
division of legislative powers to meet the new needs. So the high importance of sophisticated judicial interpretation as an ongoing process is obvious.

Let me now turn in the second place to one particular aspect of that interpretation - the proper scope to be given to the general power of the federal parliament - the power to make laws for Canada in all matters not assigned to the legislatures of the provinces. There is also a provincial general power to make laws in all matters of a merely local or private nature in the province, and, theoretically, it raises the same interpretative problems as does the federal general power. But the cases have concentrated on the federal general power, so this analysis does likewise.

The basic interpretative problem here may be explained as follows. Leaving the two general powers out of the count, there are thirty-one specific grants of powers to the federal parliament and fifteen specific ones to the provincial legislatures. Let us assume that a new statute has been passed by the federal parliament and that its validity has been challenged. The federal government now claims that the statute is valid because its primary concern is a new subject entitled to be treated as within the residuary reach of the federal general power, and thus in effect to be added to the existing list of thirty-one specific federal subjects. Accordingly our question becomes this: when is such a claim allowed for a subject not specifically listed in either section 91 or 92 , and when it is disallowed? In other words, when is it proper to enfranchise a new category to be added to the thirty-one existing specific federal categories by virtue of the residuary significance of the federal general power?

Well, look at some examples of what the courts have done about unlisted subjects. Aviation, atomic energy and the incorporation of Dominion companies have each been enfranchised as additions to the list of federal subjects by virtue of the residuary reach of the federal general power. ${ }^{12}$ But labour relations, and pollution are also completely unlisted subjects. They too are real enough as subjects of concern in our society and they have not been enfranchised as new federal subjects by virtue of the federal general power. ${ }^{13}$ Rather, each of these subjects has been itself subdivided into several parts that could be reclassified piecemeal according to some of the already established specific categories of specific categories of thirty-one federal and fifteen provincial subjects. The parts are thus distributed accordingly, some to the federal parliament and others to the provincial legislatures. Take the example of labour relations. If you have a business or industry that is under federal jurisdiction, like banks or inter-provincial railways, power to regulate their labour relations is federal. If you have a business or industry under provincial jurisdiction, like a retail store or a coal mine, power to regulate their labour relations is provincial. The same sort of point can be made about the various powers to regulate the abatement of pollution of our air, land or water. Why is the regulation of aviation made a new federal category, a unit in its own right, while labour relations is broken up and parcelled out piecemeal by the operation of several of the specific categories - the thirty-one federal ones and the fifteen provincial ones? What tests does the subject "aviation" meet that the subject "Iabour relations" fails to meet to warrant such radical difference in treatment? This is no frivolous question; it is a fundamental one about the positive operating jurisprudence of our federal system.

12 In re Regulation and Control of Aeronautics in Canada [1932] A.C. 54; Johannesson v. West St. Paul [1952] 1 S.C.R. 292; Pronto Uranium Mines Ltd. v. O.L.R.B. (1956) 5 D.L.R. (2d) 342.

13 Toronto Electric Commissioners v. Snider 1925 A.C. 396; Reference Re Industrial Relations and Disputes Investigation Act [1955] S.C.R. 529. 
To answer this question, we must first take account of the many possibilities of multiple classification or cross-classification that exist by virtue of the philosophy of the classification process itself as it relates to the distribution of legislative powers. A prohibition against emitting noxious chemicals from an industrial plant into a river, for example, may be logically classified as property law, criminal law, fisheries law, pollution law, environmental law, recreational law, public health law, and so on. Logically the prohibition may be properly characterized as any or all of these things. But which classification is to dominate for the purpose of our federal distribution of powers? Clearly, as a first step, the significant classification of a challenged law for this purpose should be sought among the specific categories listed in the B.N.A. Act. There are forty-six of them $\sqsubset$ thirty-one in the federal list and fifteen in the provincial list. If this first search among the forty-six categories does not result in a dominant classification of the challenged law satisfactory in terms of the social needs and facts of the country, then as a second step you consider invoking the federal general power. I suggest that you can take the second step and successfully invoke the federal general power if two conditions are met. First, the new subject must, as a matter of evidence, arise out of the needs of our society as something that necessarily requires country-wide regulation at the national level. Secondly, and leaving aside true emergencies, the new subject should also have an identity and unity that is quite limited and particular in its extent.

Note that whether we are assessing the impact of the forty-six specific subjects listed in the B.N.A. Act, or considering the possibility of adding a new subject to the federal list, we are not simply engaging in philosophical speculation at large about the many dozens or indeed hundreds of logically possible classifications for the challenged law.

Yet this latter range of logically possible classifications cannot be entirely ruled out of the process. Counsel seeking to invoke the federal general power in order to support a challenged federal statute on a new basis will search the whole range of dozens or hundreds of philosophically relevant classifications in order to find the one unlisted class that may serve their purpose - the one which they can then propose as a new subject for the federal list by virtue of allegedly sufficient evidence of social fact and social need for this type of regulation at the national level. If we now shift from counsel to the judges, we have an alternative statement of the basic problem. By what tests do the judges idetermine the success or the failure of such propositions from counsel about a new subject?

Perhaps I can clarify this with the example of aviation. Both the Judicial Committee and the Supreme Court of Canada have held that aviation was a subject that deserved to be added as a new specific category to the federal list by virtue of the federal general power. Why did they do this? Because technologically and industrially aviation has a factual unity as a transportation system and implications for transportation as a force in the life and development of Canada that make provincial boundaries frustrating or irrelevant, in relation to the legal regulation necessary. Read the judgment of Lord Sankey in the Aeronautics Case of $1932^{14}$ and that of Mr. Justice Locke in the Johanneson Case of 1952,15 and you will see this reasoning well expressed, especially in the words of Mr. Justice Locke. This illustrates the way in which new subjects win entitlement to be added to the federal list.

14 Supra, n. 12. 
It is interesting to note that this is the way Viscount Haldane thought of the national emergency power. Speaking of it in the Board of Commerce Case, in 1922, he located the subject of national emergency under the federal general power because it involved "conditions so exceptional that they require legislation of a character in reality beyond anything provided for by the enumerated heads in either s. 91 or s. 92 . . ."16 That is exactly the right reasoning, in accordance with my analysis. Nevertheless, as we know, Viscount Haldane went too far when he also said, in effect, that national emergency of some sort was the only subject that could qualify for status as a new subject under the federal general power. That is not in accordance with the analysis I am offering here. My analysis leads to the conclusion that the possibilities of enfranchising new specific subjects as within the federal general power are always open. They are never closed. But getting a new specific subject added to the federal list in this way has never been easy, and this is as it should be. It should in principle be very difficult to add a subject in this way, either to the federal list by virtue of the federal general power or to the provincial list by virtue of the provincial general power, which speaks of unlisted matters local in character.

Why should it be very difficult in principle to invoke the federal general power? Because it is essential in our federal country that the balance between federal and provincial subjects of primary legislative powers should remain stable and reasonably constant subject only to a process of gradual changes when these are rendered truly necessary by the demands of new conditions in our society from time to time. This applies not only to the federal general power, but of course also to the whole scheme of division of powers. Nevertheless, the cases concerned with the scope of the federal general power are the cases that raise most clearly issues of the over-all nature of our federal system, hence my concentration on those cases in this paper. The balancing and adjusting necessary is typically a task for sophisticated judicial interpretation - it is basically jurisprudential in the sense that it is an appeal to law as reason.

For the most part, I think the judges of the Judicial Committee and the Supreme Court of Canada, in their cases on the federal general power, have understood this necessity well, and have decided issues and given reasons accordingly. For me, the primary words of wisdom on the subject are those of Lord Watson, whom I consider the greatest of the Privy Council judges concerned with the Canadian constitution. In the Local Prohibition Case of 1896, he said: ${ }^{17}$

There may, therefore, be matters not included in the enumeration, upon which the Parliament of Canada has power to legislate, because the concern the peace, order, and good government of the Dominion. But to those matters which are not specified among the enumerated subjects of legislation, the exception from s. 92 , which is enacted by the concluding words of s. 91, has no application; and, in legislating with regard to such matters, the Dominion Parliament has no authority to encroach upon any class of subjects which is exclusively assigned to provincial legislatures by s. 92 . These enactments appear to their Lordships to indicate that the exercise of legislative power by the Parliament of Canada, in regard to all matters not enumerated in s. 91, ought to be strictly confined to such matters as are unquestionably of Canadian interest and importance, and ought not to trench upon provincial legislation with respect to any of the classes of subjects enumerated in s. 92. To attach any other construction to the general power which, in supplement of its enumerated powers, is conferred upon the Parliament of Canada by s. 91 , would, in their Lordships opinion, not only be contrary to the intendment of the Act, but would practically destroy the autonomy of the provinces. If it were once conceded that the Parliament of Canada has authority to make laws applicable to the whole Dominion, in relation to matters which in each province are substantially of local or private interest, upon the assumption that these matters also

16 [1922] 1 A.C. 191 at 200.

17 [1896] A.C. 348 at $360-361$. 
concern the peace, order, and good government of the Dominion, there is hardly a subject enumerated in s. 92 upon which it might not legislate, to the exclusion of the provincial legislatures. ...

Their Lordships do not doubt that some matters, in their origin local and provincial, might attain such dimensions as to affect the body politic of the Dominion, and to justify the Canadian Parliament in passing laws for their regulation or abolition in the interest of the Dominion. But great caution must be observed in distinguishing between that which is local and provincial, and therefore within the jurisdiction of the provincial legislatures, and that which has ceased to be merely local or provincial, and has become a matter of national concern, in such sense as to bring it within the jurisdiction of the Parliament of Canada.

Then, after Viscount Haldane's aberration about emergency, we come back on track with the judgment of Viscount Simon in the Canada Temperance Act Case of 1946.18 $\mathrm{He}$ cited the Local Prohibition Case with approval, and proceeded to re-state the test of the scope of the federal general power in words that are in substance the same as those of Lord Watson. ${ }^{19}$

In their Lordships' opinion, the true test must be found in the real subject matter of the legislation: if it is such that it goes beyond local or provincial concern or interests and must from its inherent nature be the concern of the Dominion as a whole (as, for example, in the Aeronautics case and the Radio case), then it will fall within the competence of the Dominion Parliament as a matter affecting the peace, order and good government of Canada, though it may in another aspect touch on matters specially reserved to the provincial legislatures. War and pestilence, no doubt, are instances; so, too, may be the drink or drug traffic, or the carrying of arms. In Russell v. The Queen, Sir Montague Smith gave as an instance of valid Dominion legislation a law which prohibited or restricted the sale or exposure of cattle having a contagious disease. Nor is the validity of the legislation, when due to its inherent nature, affected because there may still be room for enactments by a provincial legislature dealing with an aspect of the same subject in so far as it specially affects that province.

In the period since 1949, the Supreme Court of Canada has consistently followed and upheld what I would call the Watson-Simon conception of the scope of the federal general power; the Supreme Court justices have exhibited the caution and restraint that the Watson-Simon view embodies.

But this does not entirely answer the dilemma I put earlier; why was aviation treated as a new federal subject while labour relations was denied the benefit of the federal general power, divided into several parts, and distributed piecemeal in accordance with the more particular relevance of the parts to some of the original specific federal and provincial powers? In his recent distinguished essay on "Sir Lyman Duff and the Constitution", Professor Gerald Le Dain has expressed the dilemma in these terms: ${ }^{20}$

Many matters within provincial jurisdiction can be transformed by being treated as part of a larger subject or concept for which no place can be found within that jurisdiction. This perspective has a close affinity to the notion that there must be a single, plenary power to deal effectively and completely with any problem. The future of the general power, in the absence of emergency, will depend very much on the approach that the courts adopt to this issue of characterization.

What I am trying to explain and illustrate in this analysis is what Professor Le Dain perceptively pin-pointed as "this issue of characterization". In other words, am I able to answer my own question about the different treatment of aviation and labour relations as unlisted legislative subjects? I said earlier that, in normal circumstances, leaving aside true emergencies, to qualify under the federal general power a new subject should need regulation at the national level, and should also have a natural unity that is quite limited and specific in its extent - a natural unity that can be given quite particular definition philosophically. Aviation meets this test. It was a new form of transportation with a

18 [1946] A.C. 193.

${ }^{10} \mathrm{Id}$. at 206.

20 (1974) 12 Osgoode Hall L.J. 261 at 293. 
natural industrial and technological unity necessarily nation-wide in scope so far as need for legislative action was concerned. Also, as a subject, aviation is quite limited and specific in extent, relatively speaking. It is just one of many forms of transportation, and as a legislative subject it does not imply large scale trespass upon major areas of existing provincial powers. Aviation is an important subject of course, but in its legislative implications it does not take over great portions of the laws of property and civil rights or municipal institutions.

But contrast with this labour relations as a unitary legislative subject. This is no limited subject or theme, this is a sweeping subject or theme virtually allpervasive in its legislative implications. Every employer in every business or industry there is has labour relations, from the corner store to General Motors. If "labour relations" were to be enfranchised as a new subject of federal power by virtue of the federal general power, then provincial power and autonomy would be on the way out over the whole range of local business, industry and commerce as established to date under the existing heads of provincial power. The same point can be made about environmental pollution or economic growth or language requirements as unitary legislative subjects.

Notice too that this reasoning cuts both ways, it is a double-edged sword. If it were claimed that something called "culture" is, in all its aspects and as a unit, a subject that falls entirely within provincial jurisdiction because of the provincial general power over all matters of a local or private nature in the province, this would be equally contrary to the spirit and philosophy of our Canadian system for the division of legislative powers. Let me illustrate this by a quotation from an editorial in the newspaper La Presse, for Friday, November 9 th, 1973. The editorial writer, M. Guy Cormier, is asking for some definition of the phrase "cultural sovereignty". He says: ${ }^{21}$

The word "culture" is a catch-all besides being a trap.

One of the major weaknesses of the famous Laurendeau-Dunton Commission was that its work was started under the terms of a mandate which gave no definition of the word "culutre." So, why repeat the same foolish mistakes?

Nowadays, everything is cultural. A book is certainly a cultural product, as is a film, a record, or a song. But is not a song factory, or a word factory, like the C.B.C. also a cultural reality? In a way oil is also "cultural", since oil is automobiles, home comforts, a whole manner of existence and a life style.

Nowadays, therefore, everything is cultural. A notion which used to be reserved for delicate manual or mental exercise, for literature, music, painting, or needlework, is today extended to tools and computers. In this perspective, the "Boeing 747" is a modern cultural phenomenon.

In general, what we see here is the need to keep the power-conferring phrases of our federal-provincial division of powers at meaningful levels of specifics and particulars. And from this it follows that federal and provincial statutes should be drafted with sufficient detail and particularity that they take due account of those characteristics of our division of primary legislative powers. These are two sides of the same coin. No one has expressed this better than Mr. Justice Rand of the Supreme Court of Canada. In the Saumur Case in 1953 he said: ${ }^{22}$

Conceding, as in Re Alberta Legislation, that aspects of the activities of religion and free speech may be affected by provincial legislation, such legislation, as in all other fields, must be sufficiently definite and precise to indicate its subject-matter. In our political organization, as in federal structures generally, that is the condition of legislation by any authority within it: the Courts must be able from its language and its relevant circumstances, to attribute an enactment to a matter in relation to which the

21 Translation by the translation service, Ministry of Treasury, Economics and Intergovernmental Affairs, Government of Ontario (multigraphed).

22 Saumur v. City of Quebec and the A. G. for Quebec [1953] 2 S.C.R. 299 at 333. 
Legislature acting has been empowered to make laws. That principle inheres in the nature of federalism; otherwise, authority, in broad and general terms, could be conferred which would end the division of powers. Where the language is sufficiently specific and can fairly be interpreted as applying only to matter within the enacting jurisdiction, that attribution will be made; and where the requisite elements are present, there is the rule of severability. But to authorize action which may be related indifferently to a variety of incompatible matters by means of the device of a discretionary licence cannot be brought within either of these mechanisms; and the Court is powerless, under general language that overlaps exclusive jurisdictions, to delineate and preserve valid power in a segregated form. If the purpose is street regulation, taxation, registration or other local object, the language must, with sufficient precision, define the matter and mode of administration; and by no expedient which ignores that requirement can constitutional limitations be circumvented.

It is true as stated earlier that all legislative powers are distributed in Canada, but that does not mean that there is a single power, either federal or provincial, to embrace any problem or subject that can be philosophically identified as such, out of the thousands of logically possible identifications. All problems or subjects can be fitted into the total of 48 categories in sections 91 and 92 of the B.N.A. Act one way or another, and Mr. Justice Rand's point is that this must be done if federal or provincial statutes are to have validity - that they must be drafted with a particularity that has this requirement in mind. So I claim that the words of Mr. Justice Rand which I have quoted support the main thrust of my reasoning on the Canadian division of legislative powers.

A vital point about my main thesis here should now be made. As a student of Canadian federalism, I have complained by way of example of the sweeping character of "labour relations" as a single category and have said that it should in effect be treated as outside the distribution-of-powers system and broken down into several more particular parts. These parts are then each allotted, some one way and some the other, according to their particular relevance to some of the thirty-one specific federal categories and the fifteen specific provincial ones. But in breaking down one of these all-pervasive classes or subjects, we may find one or more of the resulting parts left over, so to speak. We may find that we have one or more of the several parts that do not have relevance to one of the thirty-one specific federal categories or the fifteen specific provincial categories. Now, with respect to these left-over parts, we are down to interpretative competition between the two residuary clauses. In these circumstances, the federal general power then embraces the left-over part or parts of inherent national significance or importance. The provincial residuary power in section 92(16) would likewise embrace any left-over part or parts of a merely local or private nature in the provinces.

Another example of one of these sweeping or all-pervasive categories is language - language requirements or options. Virtually all communication, thought and social organization depend on the use of language. In the case of Jones v. Attorney General of Canada last year, ${ }^{23}$ the full Supreme Court gave judgment on the constitutional validity of the federal Official Languages Act. Chief Justice Laskin gave the unanimous judgment of the Court upholding the validity of the Statute as within the powers of the federal parliament. I believe that the extent to which he used the federal general power to uphold the validity of the statute is in harmony with the general analysis I am offering here. He said: ${ }^{24}$

Apart from the effect of s. 133 and s. $91(1)$, to be considered later in these reasons, I am in no doubt that it was open to the Parliament of Canada to enact the Official Languages Act (limited as it is to the purposes of the Parliament and Government of

${ }^{23}$ Jones v. Attorney-General of Canada et al. (1974) 45 D.L.R. (3d) 583.

24 Id. at $588-589$. 
Canada and to the institutions of that Parliament and Government) as being a law "for the peace, order and good Government of Canada in relation to [a matter] not coming within the Classes of Subject ... assigned exclusively to the Legislatures of the Provinces." The quoted words are in the opening paragraph of s. 91 of the British North America Act, 1867; and, in relying on them as constitutional support for the Official Languages Act, I do so on the basis of the purely residuary character of the legislative power thereby conferred. No authority need be cited for the exclusive power of the Parliament of Canada to legislate in relation to the operation and administration of the institutions and agencies of the Parliament and Government of Canada. Those institutions and agencies are clearly beyond provincial reach.

Chief Justice Laskin then goes on to point out that the federal general power likewise supports the validity of the provisions of the federal Official Languages Act concerning the use of the English or French languages in courts properly established by federal statute, and in all criminal courts and proceedings in Canada. He adds that these are also matters respectively within the power of the federal parliament under section 101 of the B.N.A. Act, concerning the establishment of courts for the better administration of the federal laws of Canada, and the federal criminal law and procedure power in section 91(27) of the B.N.A. Act. Criminal law and procedure generally are not of course in the list of provincial powers, and so here is one very important respect in which the federal general power is indeed illustrated and re-affirmed by one of the later enumerated powers in section 91 . As I said earlier in this analysis of our power-distribution system, there is some overlapping of this kind in section 91 of the B.N.A. Act. This does not impair my main thesis that the overlapping is far from complete in the whole area of property and civil rights, in the broad historical extent of that phrase in British North America from 1774 to 1867. In any event, as I read Chief Justice Laskin, he is not saying and did not intend to say that all mandatory languages requirements and options form a single subject for purposes of the power-distribution system, a subject that would be embraced by the federal general power. I believe he is saying in effect that the subject requires considerable sub-division into several parts, which is in accordance with my analysis in this essay.

Pollution affords a further example of a sweeping category or theme that needs this piecemeal treatment for purposes of our power-distribution system. Recently the Supreme Court of Canada faced an example of this issue also, in the case of Interprovincial Co-operatives Limited and Dryden Chemicals Limited v. The Queen in Right of the Province of Manitoba. ${ }^{25}$ They gave judgment on March 26 th of this year. The majority opinion was given by Mr. Justice Pigeon. The problem concerned interprovincial rivers flowing into Lake Winnipeg, and mercury pollution of the rivers originating at points on the rivers in Saskatchewan and Ontario that allegedly ruined the fisheries in Lake Winnipeg. Mr. Justice Pigeon held that certain Manitoba legislation on the subject was beyond provincial powers, and was exclusively within federal power by virtue of the federal general power in its residuary character. But he carefully confined what he said to the pollution of interprovincial rivers bringing residents of different provinces into legal conflict with one another as to their respective legal rights and duties. This was not property and civil rights in the Province of Manitoba. This is just one of many parts or aspects into which the general subject of pollution may be sub-divided. Note that Mr. Justice Pigeon did not say or suggest in any way that pollution was a single subject for purposes of power-distribution, embraced in all its aspects by the federal general power.

Returning now for a moment to the proposition that Professor Le Dain correctly isolated as having some currency in our constitutional jurisprudence -

28 (1975) 53 D.L.R. (3d) 321. 
"the notion that there must be a single plenary power to deal effectively and completely with any problem" - I claim that this is a dangerous fallacy. To $m e$, it is a dangerous oversimplification that could lead to constitutional chaos or to the end of federalism. I infer that Professor Le Dain doesn't like the proposition any more than I do, though he does not commit himself explicitly on the point. In any event, this danger deserves some further explanation.

The philosophy of classification systems is such that any doctrinaire group that wants to push its special cause to the limit can find a subject-label for that cause that is new, so far as the established lists in the B.N.A. Act are concerned. Then the group proceeds to urge that the great importance of this new subject means that the federal parliament can and should give them the legislation they want under the federal general power. Special interest groups of all kinds can be expected to urge legislative salvation for themselves in this way, and, up to a point, this may be legitimate advocacy, but it is only advocacy and should be critically evaluated as such.

As Professor Cairns has remarked: ${ }^{26}$ "A necessary consequence of a federal system is that each organized interest will seek to transform the most sympathetic level of government into the main decision-maker in matters which concern it". One should also add that the same dangerous miscue could be made of the provincial general power in section. $92(16)$ of the B.N.A. Act. Our society is full of a great variety of groups that in many respects have conflicting interests. These considerations emphasize why we must have the caution and restraint that I have tried to spell out as the full meaning of the Watson-Simon view of the federal general power. These same considerations emphasize why it is that the superior courts, as impartial and independent interpretative tribunals, must be the umpires of the federal system of division of legislative powers. To use a figure of speech from the gambling world, if you want federalism at all, this is the only game in town, like it or not.

Having said all that, I must now add that I do not deny the reality and importance of social problems grouped under headings such as pollution, economic growth, culture, quality of life, and the like. Of course these are important generalized concepts with social reality in our country. My point is rather that categories as all-pervasive as these ones are cannot be allowed to dominate our distribution-of-powers system from within, so to speak. They must be treated as outside the system, which means they should each be subdivided into appropriate parts so that necessary legislative action can be taken by some combination of both federal and provincial statutes. Coordination of these legislative efforts should come through cooperative federalism - that is, by complementary federal and provincial statutes co-ordinated by virtue of custom, practice or inter-governmental agreements of some sort. This is a large subject in itself which I cannot develop further here. ${ }^{27}$ Suffice it to say that before you can successfully practice cooperative federalism ,you must have in place a fundamental distribution of legislative powers and resources between the central government and the provinces. The essence of cooperative federalism is federal-provincial agreement, whether tacit or explicit, about complementary uses of federal and provincial powers and resources. Hence unless the constitutional definitions of such powers and resources remain reasonably stable as the basis of the autonomy of the parties, subject only to the process of gradual

26 Supra, n. 1, at 315.

27 Lederman, W. R., "Cooperative Federalism: Constitutional Revision and Parliamentary Government in Canada", (1971) 78 Queen's Quarterly 7. "Some Forms and Limitations of Co-operative Federalism", (1967) 45 Can. Bar Rev. 409. 
adjustment I have already described, the respective bargaining positions of the two levels of government will be too uncertain for federal-provincial agreements to be reached.

Recently, the conception of the necessary operating jurisprudence of Canadian federalism that I have given at some length in this essay has come under almost total attack by Professor Paul C. Weiler, a distinguished Canadian legal scholar with long experience in the field of labour relations and collective bargaining. ${ }^{28}$ Much as I respect Professor Weiler, I must say that, on this subject, I thoroughly disagree with nearly all of what he has said.

Professor Weiler has said that the words and phrases by which our federal constitution distributes legislative powers were relevant to society and full of meaning when the constitution was first drawn up in 1867, but that, as society changed over the years in our country, these words and phrases became increasingly unreal and irrelevant to prevailing social conditions. Hence, he tells us that, 100 years later, the Supreme Court justices can really get no guidance from the original text of the B.N.A. Act, no guidance from the concepts denoted by the original words and phrases. Thus he alleges that, in making interpretative decisions today, the Supreme Court is really making up a new constitution piecemeal as it goes along, and not doing it very well at that. Now I would agree that a final judicial interpretative tribunal has important degrees of discretion here, as in other parts of the law, but Professor Weiler goes much too far in what he has said.

I think Professor Weiler has got his history backwards. I consider the true history of the development of the B.N.A. Act by judicial interpretation to be almost the complete reverse of what Professor Weiler says it is. As I said early in this essay, the greatest uncertainty about the meaning of the power-conferring words and phrases of the constitution, in relation to one another, occurred at the beginning. As time went on and precedents accumulated, many years of judicial interpretation greatly reduced this uncertainty and made the distribution-ofpowers system much more meaningful. In other words, after one hundred years of judicial interpretation, the B.N.A. Act has become much more meaningful than it was in 1867, and of course it was by no means devoid of meaning in 1867 . We are talking of matters of degree and of the main trends, positive or negative, in the development of the meaning and utility of the constitution. Moreover, judicial interpretation over the years has shaped the original power-conferring words and phrases, in relation to one another, so that they have been capable of affording guide-lines for new problems of legislative power-distribution arising from social change. This parallels the function and operation of judicial precedent in other branches of the law, so there should be nothing surprising about it.

Now in saying this, I am definitely not saying that the B.N.A. Act is complete and all-sufficient in the sense that it contains in its text detailed principles and concepts that automatically embody easy solutions for every problem in the division of legislative powers that may arise. If this were so, reading the Act would be all that was involved in constitutional interpretation. I know that this extremely simplistic view of interpretation and meaning is not valid. But Professor Weiler has gone to the opposite extreme. He says that the federal constitution has become virtually meaningless, so that the Supreme Court is really making up new constitutional rules as it goes along under the guise of interpreting the text of the B.N.A. Act. This extreme is just as invalid as the

28 "Law and Social Change", Osgoode Hall Lecture Series, Ziegel (ed.) (1973) Chapter 3, with critical comment by W. R. Lederman. Paul Weiler, In the Last Resort, (1974), Carswell/Methuen, Toronto, Chapter 6. 
other. It does not properly describe our true operating federal jurisprudence either. As usual, the truth lies at some middle position between these opposed extremes. I think Professor Weiler has gravely over simplified the nature of constitutions and constitutional history.

Logically enough as a result of his views, however, Professor Weiler considers that we would be better off if the courts in general, and the Supreme Court of Canada in particular, were out of the business of judicial review of the federal constitution altogether. He would look instead to the model afforded by collective bargaining in labour relations for the operational jurisprudence of our federal system - he would put the main issues of the federal constitution into rather constant negotiation at federal-provincial conferences of our elected political leaders of government. For my part, I think these latter gentlemen already have quite enough to do operating within the guidelines afforded by judicial review of the constitution.

In the latest version of his views, published last year, Professor Weiler does concede a marginal role for the courts. ${ }^{29}$. If some unfortunate citizen is caught by actual conflict of federal and provincial statutes applicable to him, Professor Weiler would allow him to go to court. But, to me, this latest qualification simply makes Mr. Weiler's main position less credible than ever. Conflict or inconsistency is a complex and flexible idea. There are thousands of pages in the federal statute books, and tens of thousands of pages in the provincial statute books, to say nothing of subordinate legislation. A good counsel could nearly always find enough conflict or inconsistency of some kind to get into court, and you would be back to full-fledged judicial review.

In any event, I do not find the model afforded by labour relations jurisprudence in Canada to be satisfactory as a type of system for control of the operating fundamentals of our federal constitution. I repudiate the labour relations model as a substitute for sophisticated judicial review at the highest levels in these fundamental matters. It is to the latter that we must look for a satisfactory operating jurisprudence of Canadian federalism, and, while this is centred on the courts, it does not involve the courts alone. To quote Professor Cairns again: ${ }^{30}$

A strong and effective court requires a variety of supporters. It must be part of a larger system which includes first class law schools, quality legal journals, and an able and sensitive legal fraternity-both teaching and practicing. These are the minimum necessary conditions for a sophisticated jurisprudence without which a distinguished judicial performance is impossible. Unless judges can be made aware of the complexities of their role as judicial policy-makers, and sensitively cognizant of the societal effects of their decisions, a first rate judicial performance will only occur intermittently and fortuitously.

I say "Amen" to that, but again I feel both chastened and challenged. I have not yet said anything about my own views on this thing called policy-making, and to leave that out these days is to risk being characterized as a mere technician.

I do maintain that respectable beliefs in the realm of values lie behind the views I have expressed here. In the first place, a good federal division of legislative powers honours the values of pluralism - of the diversities in our society - as well as the need for a certain amount of unity. This assumes sophisticated and socially sensitive interpretation of the power-conferring words and phrases by impartial courts, especially the Supreme Court of Canada. The jurisprudential problem then is to achieve a -balance between carefully defined unities and carefully defined diversities, the definitions collectively being comprehensive or

${ }^{29}$ Id.

${ }^{30}$ Supra, n. 1, at 331. 
potentially so. I have argued that it is a necessary part of our system to hold the definitions of federal and provincial categories of powers to a meaningful level of specific identity and particularity. The value of this is that, when we analyse our legislative needs, the issues requiring value decisions are rendered specific and brought into focus one by one in particular terms, so that ordinary mortals of limited wisdom and moral insight can cope with them. We are all ordinary mortals, so it is no use setting up a system that only God could operate. Moreover, I prefer federal systems to unitary ones because I believe in countervailing power among human institutions. I like to see our Federal Government having to compromise with Provincial Governments, and vice versa. I feel more secure as a citizen when the system requires this.

In the second place, it is necessary that impartial superior courts should act as umpires of the essential guidelines for the respective federal and provincial responsibilities given by the federal constitution. Of course the value assumptions of the judges will enter into their decisions. We would complain if this were not so. They must weigh such matters as the relative values of nation-wide uniformity versus regional diversity, the relative merit of local versus central administration, and the justice of minority claims, when provincial or federal statutes are challenged for validity under the established division of powers. Inevitably, widely prevailing beliefs in the country about these issues will be influential and presumably the judges should strive to implement such beliefs. Inevitably there will be some tendency for them to identify their own convictions as those which generally prevail or which at least are the right ones. On some matters there will not be an ascertainable general belief anyway. In the making of these very difficult decisions of relative values - policy decisions if you prefer that word - all that can rightly be demanded of judges is straight thinking, industry, good faith, and a capacity to discount their own prejudices with due humility. No doubt it is also fair to ask that they be men or women of high professional attainment, and that they be somewhat representative in their thinking of the better standards of their times and their fellow citizens. 